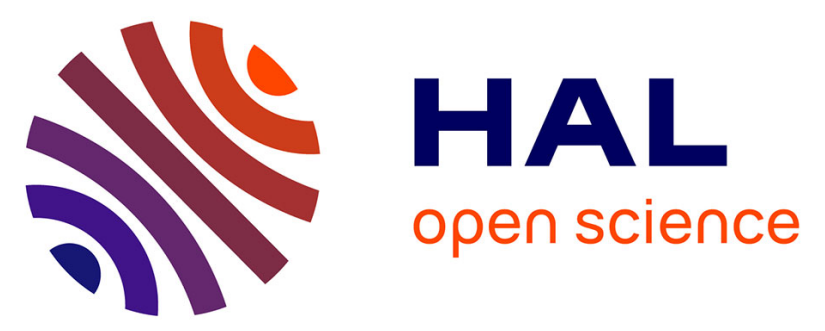

\title{
Immune response to Haemonchus contortus infection in susceptible (INRA 401) and resistant (Barbados Black Belly) breeds of lambs
}

G Terefe, Caroline C. Lacroux, Olivier Andréoletti, Christelle C. Grisez, Françoise Prevot Prévot, Jean-Paul Bergeaud, J Penicaud, Virginie Rouillon,

L Gruner, Jean-Claude Brunel, et al.

\section{To cite this version:}

G Terefe, Caroline C. Lacroux, Olivier Andréoletti, Christelle C. Grisez, Françoise Prevot Prévot, et al.. Immune response to Haemonchus contortus infection in susceptible (INRA 401) and resistant (Barbados Black Belly) breeds of lambs. Parasite Immunology, 2007, 29 (8), pp.415-424. 10.1111/j.13653024.2007.00958.x . hal-02660400

\section{HAL Id: hal-02660400 \\ https: / hal.inrae.fr/hal-02660400}

Submitted on 30 May 2020

HAL is a multi-disciplinary open access archive for the deposit and dissemination of scientific research documents, whether they are published or not. The documents may come from teaching and research institutions in France or abroad, or from public or private research centers.
L'archive ouverte pluridisciplinaire HAL, est destinée au dépôt et à la diffusion de documents scientifiques de niveau recherche, publiés ou non, émanant des établissements d'enseignement et de recherche français ou étrangers, des laboratoires publics ou privés. 


\title{
Immune response to Haemonchus contortus infection in susceptible (INRA 401) and resistant (Barbados Black Belly) breeds of lambs
}

\author{
G. TEREFE, ${ }^{1,6}$ C. LACROUX,${ }^{2,6}$ O. ANDREOLETTI,${ }^{2}$ C. GRISEZ,${ }^{2}$ F. PREVOT, ${ }^{2}$ J. P. BERGEAUD,${ }^{2}$ J. PENICAUD, ${ }^{2}$ \\ V. ROUILLON,${ }^{2}$ L. GRUNER, ${ }^{3}$ J. C. BRUNEL, ${ }^{4}$ D. FRANCOIS,${ }^{5}$ J. BOUIX, ${ }^{5}$ P. DORCHIES ${ }^{2} \&$ P. JACQUIET ${ }^{2}$
}

${ }^{1}$ Addis Ababa University, Faculty of Veterinary Medicine, Debre-Zeit, Ethiopia, ${ }^{2}$ UMR INRA-ENVT 1225 Interactions Hôtes Agents Pathogènes: Ecole Nationale Vétérinaire de Toulouse, Toulouse Cedex, France, ${ }^{3}$ INRA, Ecologie et Génétique des Parasites, BioAgresseurs Santé et Environnement, Nouzilly, France, ${ }^{4}$ INRA, Domaine Expérimental de la Sapinière, Osmoy, France, ${ }^{5}$ INRA, Station d'Amélioration Génétique des Animaux, Castanet-Tolosan, France

\section{SUMMARY}

The immune responses to Haemonchus contortus were compared in studies in resistant Barbados Black Belly (BBB) and susceptible INRA 401 (INRA) breeds of lambs. The cytokine patterns indicated a Th2-biased response in both breeds. A more persistent and elevated Th2 cytokine $m R N A$ transcription and blood eosinophilia were noted in the BBB lambs. However, at days 4 and 30 post-infection, abomasal recruitment of eosinophils and mast cells were similar between the two breeds. Following primary infections, the $B B B$ demonstrated a substantially lower faecal egg count compared to the INRA lambs. Furthermore, worm counts at 4 and 30 days postinfection, and adult female worm size and in utero egg counts 30 days after the first infection were significantly lower in the $B B B$ than in the INRA breed. In the INRA breed, re-infection caused a significant reduction in most parasitological parameters compared with those observed after the primary infection. A similar response was not observed in the BBB sheep. In conclusion, while the major driving force in the response to $\mathrm{H}$. contortus infection is a Th2-biased immunity in which the $B B B$ showed its maximal performance during the primary infection, the INRA breed performed better after re-infection compared to its response to first exposure.

Keywords Black Belly, cytokines, effector cells, Haemonchus contortus, INRA-401, sheep

Correspondence: P. Jacquiet, UMR INRA-ENVT 1225 Interactions Hôtes Agents Pathogènes: Ecole Nationale Vétérinaire de Toulouse, 23, chemin des Capelles, 31076 Toulouse Cedex 03, France (e-mail: p.jacquiet@envt.fr).

${ }^{6}$ Both authors have contributed equally to this study.

Re-submitted to Parasite Immunology, May 2007.

Received: 27 February 2007

Accepted for publication: 9 May 2007

\section{INTRODUCTION}

Rapid expulsions of primary nematode infections can occur in most murine models $(1,2)$ while in ruminants, elimination of adult nematodes from the GI tract commonly occurs as a consequence of the development of adaptive immunity (3). In this respect, $\mathrm{CD} 4^{+} \mathrm{T}$ lymphocytes are said to play a pivotal role in mediating resistance to Haemonchus contortus in sheep $(4,5)$, and significantly higher lymphocyte blastogenic responses to parasite antigen have been reported in animals with genetic resistance to haemonchosis (6). Moreover, $H$. contortus infections in lambs have been shown to induce a Th2-polarized adaptive immune response with mobilization of characteristic effector cells (mast cells, eosinophils) and production of immunoglobulin isotypes such as $\operatorname{IgA}, \operatorname{IgG} 1$ and $\operatorname{IgE}(7,8)$. The relative importance of the different effector mechanisms in influencing parasite development is still under discussion, but their involvement in the regulation of nematode populations is now generally accepted (9-11). While a reduction in larval establishment and their subsequent development into adult stages is considered as a 'final point' of the adaptive immune response to GI nematodes (12), diminished female worm size and reduced fecundity are major regulatory forces for gastrointestinal parasitic populations in lambs $(7,13)$. However, there is evidence, which indicates that these responses can be influenced by factors including the genetic background of the animals. Inter-breed and within-breed variations in the response to infection with $H$. contortus in sheep have been demonstrated in a number of studies (14-17). Similarly, using different isolates of $H$. contortus, the Barbados Black Belly (BBB) breed has been shown to be more resistant than the INRA 401 (INRA) breed (18). In addition, Gruner et al. (19) found that a similar resistance of this breed was observed in infections with Trichostrongylus colubriformis and, to a lesser extent, with Teladorsagia circumcincta. While comparisons have been made to elucidate differences in parasitological parameters 
between these two breeds, little or no attempt has been made to reveal the potential immune mechanisms underlying such differences. The objective of this study was to compare immunological mechanisms such as cytokine gene expressions and effector cell (eosinophils, mast cells, etc.) and antibody responses between the resistant (BBB) and the susceptible (INRA 401) breed relative to the development of their $H$. contortus populations after experimental infection.

\section{MATERIALS AND METHODS}

\section{Animals and experimental infections}

Six-month-old male INRA $401(n=28)$ and BBB lambs $(n=25)$ which had been reared and were maintained under worm-free conditions were randomly allocated, for each breed, into three experimental groups: Group A (previously infected, dewormed and re-infected), Group B (primaryinfected) and Group C (uninfected control) sheep. Lambs received concentrate feed appropriate for their age, and hay and water were available ad libitum. Animals were handled according to the European Union recommendations for animal welfare, and were under the supervision of the local INRA ethics committee.

In Phase I, lambs of Group A were infected on $\mathrm{D}_{0}$ with $10^{4} \mathrm{H}$. contortus infective larvae $\left(\mathrm{L}_{3}\right)$ (Humeau strain) followed by treatment of all lambs (Groups A-C) with oral ivermectin (Oramec ${ }^{\circledR} 0.2 \mathrm{mg} / \mathrm{kg}$, Merial SAS) on $\mathrm{D}_{30}$. In Phase II, lambs of Group A were re-infected on $\mathrm{D}_{45}$ with $10^{4} H$. contortus $\mathrm{L}_{3}$, at the same time as those of Group B received their first infection with the same number of larvae. The animals were killed either on $\mathrm{D}_{49}, 4$ days post-challenge (dpc) or on $\mathrm{D}_{75}(30 \mathrm{dpc})$ by administration of intravenous barbiturate followed by exsanguinations (Table 1).

\section{Parasitological measurements}

Egg counts were performed according to the modified McMaster technique (20) on rectal faecal samples collected twice a week from $\mathrm{D}_{16}$ to $\mathrm{D}_{30}$ (Phase I) and from $\mathrm{D}_{59}$ to $\mathrm{D}_{75}$ (Phase II) after infection. Immediately after necropsy, the contents and washings of the abomasums were collected and processed as described previously $(21,22)$ for worm counting, and female worm size measurement and in utero egg counts.

\section{Blood eosinophil counts}

Blood samples were collected in EDTA coated tubes once a week from $\mathrm{D}_{0}$ to $\mathrm{D}_{45}$ for Group $\mathrm{A}$ in the first phase and from $\mathrm{D}_{45}$ to $\mathrm{D}_{75}$ for all groups in the second phase. Eosinophil counts were performed after staining with eosin Y $0.5 \%$ (Ref. 6766009, Thermo Electron Co., USA) as described previously $(22,23)$.

\section{mRNA extraction and quantification of cytokine gene expression}

After necropsy, about $300 \mathrm{mg}$ of abomasal lymph node (ALN) or fundic mucosal samples were snap frozen in $1 \mathrm{~mL}$ of Trizol Reagent (Invitrogen reference 15596-018), and preserved at $-70^{\circ} \mathrm{C}$ for mRNA extraction, and subsequent amplification and quantification of cytokine gene expressions by reverse transcription-polymerase chain reaction (RT-PCR) and quantitative-PCR as described previously (7).

\section{Histology and immunohistochemistry (IHC)}

Two samples from the abomasal fundic region were taken from necropsied animals; one was fixed in 10\% formalin for conventional histology and IHC while the second was stored at $-70^{\circ} \mathrm{C}$ for frozen IHC analysis.

Abomasal tissue was paraffin-embedded and $3 \mu \mathrm{m}$ sections were mounted on glass slides. Eosinophils and globule leucocytes were counted on haematoxylin-eosin stained sections whereas mast cells were counted after staining with Giemsa. IHC on paraffin-embedded tissues was performed using antibodies previously described for cell phenotyping

Table 1 Experimental design

\begin{tabular}{|c|c|c|c|c|c|c|}
\hline \multirow[b]{2}{*}{ Breed } & \multirow[b]{2}{*}{ Group } & \multirow{2}{*}{$\begin{array}{l}\text { Phase I } \\
\text { infection } \\
\text { Day } 0\end{array}$} & \multirow{2}{*}{$\begin{array}{l}\text { Anthelmintic } \\
\text { treatment } \\
\text { Day } 30\end{array}$} & \multirow{2}{*}{$\begin{array}{l}\text { Phase II } \\
\text { infection } \\
\text { Day } 45\end{array}$} & \multicolumn{2}{|c|}{ Number of sheep killed } \\
\hline & & & & & Day 49 & Day 75 \\
\hline \multirow[t]{3}{*}{ INRA } & Group A & + & + & + & $n=5$ & $n=5$ \\
\hline & Group B & - & + & + & $n=5$ & $n=5$ \\
\hline & Group C & - & + & - & $n=4$ & $n=4$ \\
\hline \multirow[t]{3}{*}{ BBB } & Group A & + & + & + & $n=4$ & $n=5$ \\
\hline & Group B & - & + & + & $n=4$ & $n=5$ \\
\hline & Group C & - & + & - & $n=3$ & $n=4$ \\
\hline
\end{tabular}


on paraffin-embedded tissues in sheep (7). This antibody set allows specific labelling of macrophages/monocytes, B lymphocytes or T lymphocytes.

For IHC on frozen samples, $5 \mu \mathrm{m}$ sections of abomasal tissue were obtained using a Leika cryomicrotome. Slides were fixed for $20 \mathrm{~min}$ in an acetone bath at $-20^{\circ} \mathrm{C}$ before drying and were immediately processed. Monoclonal antibodies directed against CD4 (mouse anti-ovine CD4, SEROTEC, reference MCA2213, $1: 2000$ dilution) or CD8 (mouse anti-bovine CD8, SEROTEC, reference MCA837G, $1: 800$ dilution) antigens were used. In all cases, cells were counted on five randomly selected microscopic fields at $\times 400$ magnification.

\section{Antibody responses}

Preparation of serum and $\mathrm{H}$. contortus antigens

Antibody measurements were performed on regularly collected sera and mucus samples, which were collected after necropsy using a $4 \mathrm{~cm}^{2}$ PBS-impregnated filter paper strip placed on the abomasal mucosa. Mucus was eluted by gently agitating the strips in PBS for $2 \mathrm{~h}$ at room temperature. The liquid was then centrifuged and the supernatant was stored at $-70^{\circ} \mathrm{C}$ until used. Excretion-secretion products (ESP) from adult $H$. contortus were prepared by incubating the worms in PBS ( $\mathrm{pH} 7 \cdot 4$ ) containing penicillin (100 IU/ $\mathrm{mL})$ and streptomycin $(1 \mathrm{mg} / \mathrm{mL})$ at $37^{\circ} \mathrm{C}$ with $5 \% \mathrm{CO}_{2}$ overnight. The fluid was centrifuged $\left(10000 \mathrm{~g}, 30 \mathrm{~min}, 4^{\circ} \mathrm{C}\right)$, and the supernatant was stored at $-70^{\circ} \mathrm{C}$ for use as an antigen. A crude extract of $H$. contortus $\mathrm{L}_{3}\left(\mathrm{~L}_{3} \mathrm{CE}\right)$ was prepared after three cycles of freezing and thawing $\left(-70^{\circ} \mathrm{C} /+25^{\circ} \mathrm{C}\right)$, homogenization at $4^{\circ} \mathrm{C}$ and centrifugation at $30000 \mathrm{~g}$ for $30 \mathrm{~min}$ at $4^{\circ} \mathrm{C}$. The supernatant was stored as above. The protein concentration of these two antigenic preparations was determined using the method of Lowry et al. (24).

\section{ELISA for $\operatorname{Ig} G$ and $\operatorname{Ig} A$ antibodies}

An indirect ELISA was applied on serum and mucus samples as described by Jacquiet et al. (25) to determine H. contortus ESP-specific IgG, and $\mathrm{L}_{3} \mathrm{CE}$-specific IgG and $\mathrm{IgA}$ responses, respectively. Briefly, each well of a flat-bottomed microtitre plate (Nunclon Distr. VWR International, France) was coated overnight with $100 \mu \mathrm{L}$ of antigen diluted in sodium carbonate buffer at $4^{\circ} \mathrm{C}$. The plates were washed twice in PBS pH $7 \cdot 2$ containing $0 \cdot 1 \%$ Tween 20 (PBS-T). To minimize nonspecific binding of the antibody, the plates were then incubated for $1 \mathrm{~h}$ at $37^{\circ} \mathrm{C}$ with $200 \mu \mathrm{L}$ of 5\% skimmed milk PBS-T (PBS-TSM). Subsequently the PBS-TSM was discarded and the plates dried, before adding $100 \mu \mathrm{L}$ of serum diluted in PBS-TSM or nondiluted mucus to each well for $1 \mathrm{~h}$ at $37^{\circ} \mathrm{C}$. After three washes with PBS-T (the third being for $5 \mathrm{~min}$ ), the plates were subsequently incubated for $1.5 \mathrm{~h}$ with $100 \mu \mathrm{L}$ of donkey anti-sheep $\mathrm{IgG}$ HRP (Sigma, reference A3415) for IgG determination, or for IgA determination, for two periods of $1 \mathrm{~h}$ with the first (mouse IgG1 anti-IgA bovine/ovine, Serotec, reference MCA628) and the second (goat anti-mouse IgG1 HRP, Serotec, reference STAR81P) conjugates separated by three washings in PBS-T. Finally, the plates were washed three times with PBS-T and $100 \mu \mathrm{L}$ of 2-2'-azino-bis(3-ethylbenylthiazoline-6-sulphonic acid, ABTS) in $100 \mathrm{~mm}$ citrate buffer (Sigma, reference 104.4), containing 0.01\% $\mathrm{H}_{2} \mathrm{O}_{2}$ was added to each well. The colour was allowed to develop for $1 \mathrm{~h}$ at $37^{\circ} \mathrm{C}$ before the reaction was stopped by maintaining the plates at $4^{\circ} \mathrm{C}$ for $15 \mathrm{~min}$. The optical density was measured at $405 \mathrm{~nm}$ using a Microplate Reader (System Dias, Dynatech).

\section{Serum pepsinogen}

Serum pepsinogen concentrations were evaluated as previously described by Dorny and Vercruysse (26). Briefly, the serum sample was acidified with $\mathrm{HCl}$ and incubated overnight at $37^{\circ} \mathrm{C}$ with bovine serum albumin (BSA). The reaction was stopped with $4 \%$ trichloro-acetic acid (TCA) and the mixture was centrifuged at 14000 r.p.m. for $5 \mathrm{~min}$. An aliquot from the supernatant was added to $0.25 \mathrm{M}$ $\mathrm{NaOH}$ and the plates were incubated at room temperature with folin reagent for $30 \mathrm{~min}$. The liberated tyrosine was estimated by reading the absorbance at $680 \mathrm{~nm}$ and the values were expressed as $\mathrm{mU}$ tyrosine/L of serum.

\section{Statistical analysis}

Comparisons between Groups (A-C), between the two necropsy dates $\left(\mathrm{D}_{49}\right.$ and $\left.\mathrm{D}_{75}\right)$ within a group and between the two breeds (BBB, INRA 401) for a given group were performed using Kruskal-Wallis nonparametric tests (SYSTAT software). $P<0.05$ was considered significant. The kinetics of faecal egg count (FEC), blood eosinophil counts, pepsinogen concentrations and serum antibody responses were compared between experimental groups and breeds using repeated measures ANOVA (SYSTAT software). Within-subject comparisons are not shown.

\section{RESULTS}

\section{Parasitological values}

Faecal egg excretion

No faecal egg excretion was recorded in lambs of Groups C throughout the experimental period. This was confirmed by the absence of worms in the abomasum at necropsy. During the immunizing infection (Group A: Phase I), faecal egg 

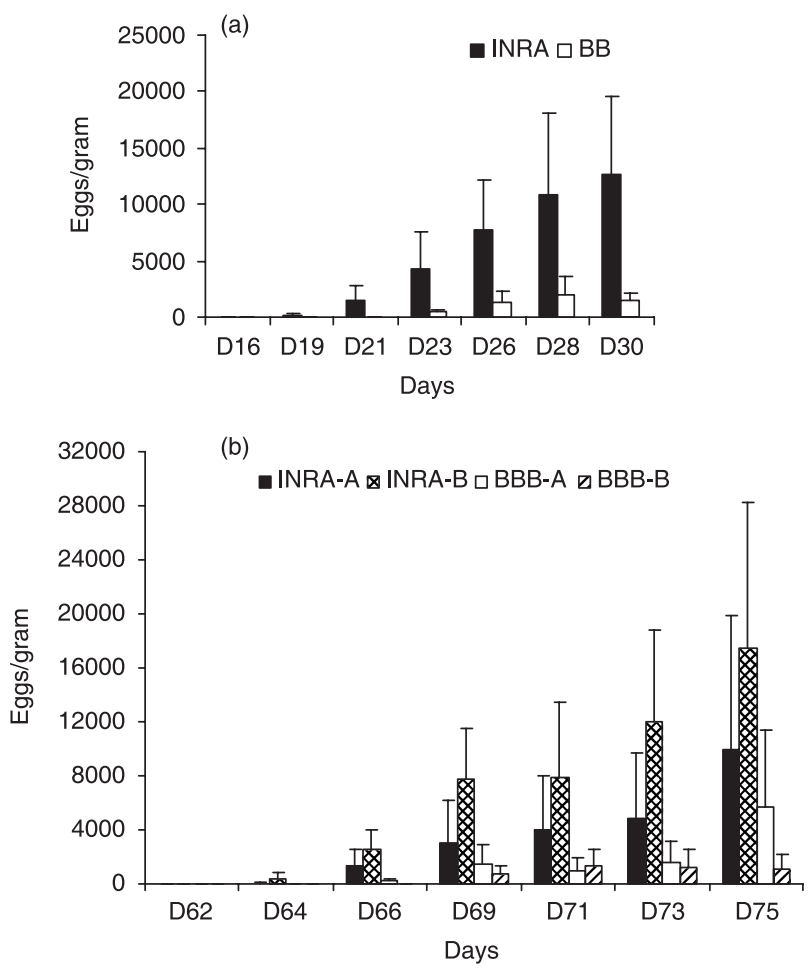

Figure 1 Faecal egg excretions in BBB and INRA breeds of lambs during: (a) Phase I (Group A) and (b) Phase II (Groups A and B). Animals were infected with $10000 \mathrm{H}$. contortus L3. The primaryinfection in Group A animals was terminated by oral ivermectin 2 weeks before re-infection with the same dose.

excretion started on $\mathrm{D}_{19}$ in the INRA lambs while it was delayed for about 4 days $\left(D_{23}\right)$ in the $\mathrm{BBB}$ lambs (Figure 1a). Furthermore, FECs in the BBB animals were significantly lower than those recorded for the INRA breed
$(P<0 \cdot 001)$. In Phase II, the first eggs were observed in the faeces 19 and 21 days after infection, respectively, for INRA and BBB lambs (Figure 1b). The difference between Groups A (re-infected) and B (primary-infected) within a breed was not significant. Similar to the observations during the first infection of Group A, the FEC's were lower in the BBB Group B than in INRA Group B lambs $(P=0 \cdot 005)$. However, this difference was absent between the two breeds after re-infection.

\section{Worm burden and adult female worm size and fecundity}

On $\mathrm{D}_{49}(4 \mathrm{dpc})$, both infected BBB Groups (A and B) exhibited significantly lower fourth stage larval counts than their INRA counterparts while there was no difference in the counts between Groups A and B within a breed (Table 2). On $\mathrm{D}_{75}(30 \mathrm{dpc})$, there was no statistical difference in worm counts between the INRA Group A and B lambs; at this time only the BBB Group B lambs had fewer worms than both INRA groups. Surprisingly, higher worm burdens were registered $(P=0.05)$ in the re-infected BBB lambs of Group A compared with those in the primary-infected lambs of this breed (Group B). Worms of all developmental stages ( $\mathrm{L}_{4}$ to adults) were present in all infected groups. Reinfection in the INRA lambs resulted in higher percentages of L4 and immature stages and reductions in female worm length and in utero egg counts (Table 2) when compared with Group B animals of this breed. However, after the second exposure to infection in the BBB animals there were no significant changes in these parameters compared with those observed after the primary infection. Both infected BBB Groups had significantly lower numbers of eggs in utero and reduced female worm size than the primaryinfected INRA lambs $(P<0 \cdot 01)$. However, values for these parameters in the BBB lambs were not statistically different from those of INRA Group A lambs.

Table 2 Parasitological parameters measured from samples collected at $4\left(D_{49}\right)$ and $30\left(D_{75}\right)$ days post-challenge. All infected groups have received $10000 \mathrm{H}$. contortus L3 at a time. Animals were killed either at 4 or at 30 days post-infection

\begin{tabular}{|c|c|c|c|c|c|c|c|c|c|}
\hline $\begin{array}{l}\text { Days post- } \\
\text { challenge }\end{array}$ & Breed & Group & $\begin{array}{l}\text { Total worm } \\
\text { burden } \\
(\text { mean } \pm \mathrm{SD})\end{array}$ & $\mathrm{L}_{4}(\%)$ & $\begin{array}{l}\text { Immature male } \\
\text { and female }(\%)\end{array}$ & $\begin{array}{l}\text { Adult } \\
\text { males }(\%)\end{array}$ & $\begin{array}{l}\text { Adult } \\
\text { females }(\%)\end{array}$ & $\begin{array}{l}\text { Adult female } \\
\text { length } \\
(\text { mean } \pm S D)\end{array}$ & $\begin{array}{l}\text { Number of eggs } \\
\text { in utero }(\mathrm{mm}) \\
\text { (mean } \pm \mathrm{SD})\end{array}$ \\
\hline \multirow[t]{4}{*}{$4 \mathrm{dpc}$ (D49) } & \multirow[t]{2}{*}{ INRA } & A & $1650 \pm 467^{\mathrm{a}}$ & 100 & - & - & - & - & - \\
\hline & & B & $1892 \pm 535^{\mathrm{a}}$ & 100 & - & - & - & - & - \\
\hline & \multirow[t]{2}{*}{$\mathrm{BBB}$} & A & $695 \pm 458^{\mathrm{b}}$ & 100 & - & - & - & - & - \\
\hline & & B & $1205 \pm 246^{\mathrm{b}}$ & 100 & - & - & - & - & - \\
\hline \multirow{4}{*}{$30 \mathrm{dpc}(\mathrm{D} 75)$} & \multirow{2}{*}{ INRA } & A & $4370 \pm 902^{\mathrm{a}}$ & 15 & 13 & 34 & 38 & $16 \cdot 8 \pm 1 \cdot 2^{\mathrm{a}}$ & $334 \pm 201^{\mathrm{a}}$ \\
\hline & & B & $5558 \pm 1763^{\mathrm{a}}$ & 6 & 6 & 41 & 47 & $19 \cdot 8 \pm 1 \cdot 4^{\mathrm{b}}$ & $713 \pm 129^{b}$ \\
\hline & \multirow[t]{2}{*}{$\mathrm{BBB}$} & A & $4274 \pm 1980^{a}$ & 8 & 9 & 40 & 43 & $14 \cdot 8 \pm 1 \cdot 9^{\mathrm{a}}$ & $234 \pm 120^{\mathrm{a}}$ \\
\hline & & $\mathrm{B}$ & $2465 \pm 1623^{b}$ & 10 & 25 & 35 & 30 & $14 \cdot 6 \pm 1 \cdot 2^{\mathrm{a}}$ & $180 \pm 70^{\mathrm{a}}$ \\
\hline
\end{tabular}

Means with different letters on the same column are significantly different for each autopsy date $(P<0 \cdot 05)$. 


\section{Patterns of cytokine mRNA gene expression}

For both breeds, $H$. contortus infections were followed by a significant increase in $\mathrm{Th}_{2}$ cytokine (IL-4, IL-5 and IL-13) gene expression in the abomasal fundic mucosa (AFM) and ALN while these values remained low and constant in control animals (Figure 2). This was noticed earlier (4 dpc) in the re-infected groups than in the primary-infected groups especially in the ALN samples. There was no significant difference in cytokine mRNA transcriptions in the AFM between groups, breeds or between the two necropsy dates. In contrast, the IL-4, IL-5 and IL-13 mRNA transcription levels were considerably elevated $30 \mathrm{dpc}$ in the ALN of infected BBB compared with those in the INRA lambs $(P<0 \cdot 05)$. Moreover, IL-5 gene transcription was found to be drastically down-regulated at $30 \mathrm{dpc}$ in both infected INRA groups compared levels observed at $4 \mathrm{dpc}$. The IL-4, IL-5 and IL-13 gene expression values were highly correlated $(0.85<r<0.95)$ in both breeds. No clear interbreed or group differences in IFN- $\gamma$, IL-12, IL-10, TNF- $\alpha$ and eotaxin mRNA transcriptions were recorded (data not shown).

\section{Cell recruitment in blood and abomasal mucosa}

In the control groups, circulating eosinophil counts remained low and stable throughout the experimental period (Figure 3). In infected groups, peak values were observed 2 3 weeks after infection. During both experimental infections, blood eosinophil counts were higher in the BBB lambs than in the INRA lambs $(P<0.001)$. After anthelmintic treatment, eosinophil counts returned to pre-infection levels within 2 weeks in the INRA lambs but remained higher than control values in the BBB lambs. However, re-infection in the BBB animals was followed by a further increase in blood eosinophil counts $(P<0.05)$ compared with the primary infection; this was not observed in the INRA lambs. Blood eosinophilia was negatively associated with FEC and/or female worm length $(-0.87>r>-0.99)$ in the INRA breed while a similar relationship was only observed with worm burden in the BBB Group B lambs $(r=-0.95)$.

Numbers of mast cells, globule leucocytes and eosinophils in the AFM were very low in uninfected control animals (Figure 4). In both breeds, an increase in cell recruitment was obvious only $30 \mathrm{dpc}$ in the primary-infected groups but
Figure 2 Cytokine mRNA transcriptions for IL-4, IL-5 and IL-13 in the abomasal fundic mucosa (a, c, e) and abomasal lymph node (b, $d, f)$ in infected and control groups at 4 and $30 \mathrm{dpc}$. Assays were performed using an external standard and results were expressed after normalization (ratio) with a housekeeping gene (ovine $\beta$-actin). Asterisks indicate statistical differences between the two breeds $(P<0 \cdot 05)$
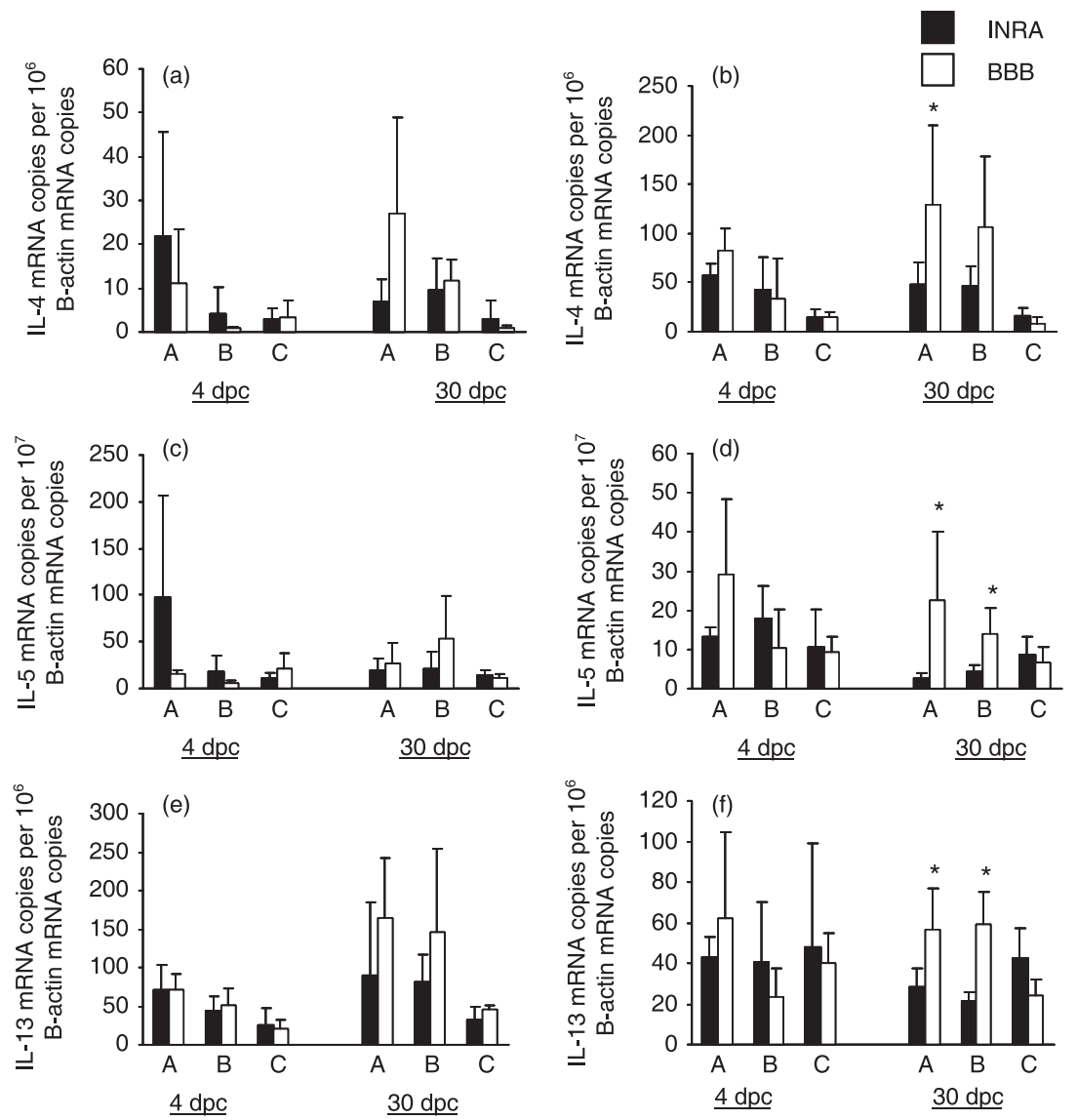


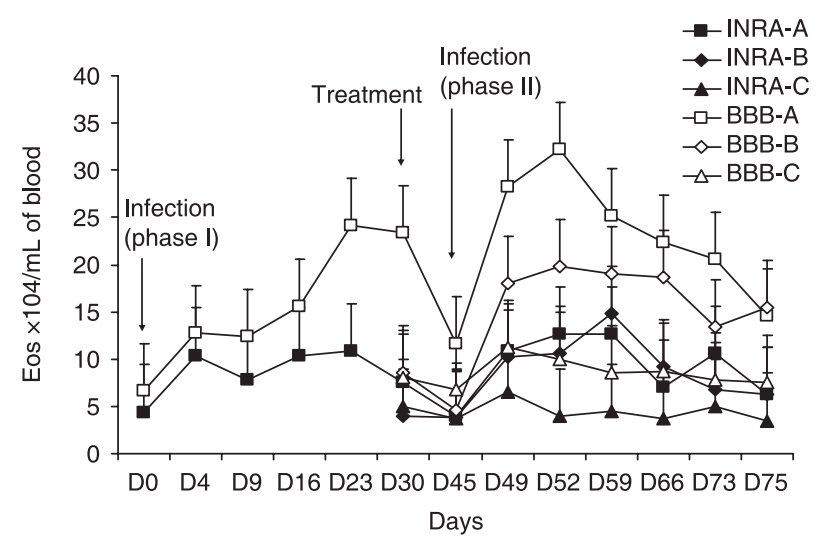

Figure 3 Mean blood eosinophilia in the BBB and INRA lambs following primary infection and re-infection with $H$. contortus. Eosinophilia in control groups was evaluated during the second phase.

was already prominent $4 \mathrm{dpc}$ in the re-infected groups. With the exception of mast cells, cellular recruitment into the AFM was similar between groups and between breeds at both 4 and $30 \mathrm{dpc}$. Higher counts of mast cells were noticed 4 days after re-infection in the BBB lambs and 30 days post-primary infection in the INRA lambs. Counts were comparable between breeds and between groups for $\mathrm{CD}^{+}$T cells, BLA $36^{+}-\mathrm{B}$ cells, CD $68^{+}$-monocyte/macrophage cells and $\mathrm{CD}^{+}: \mathrm{CD}^{+}$ratio in the abomasal mucosa (data not shown). Abomasal eosinophils in both groups of BBB lambs and mast cells in the INRA Group A lambs were positively correlated to levels of IL-5 mRNA expressions $(0 \cdot 85<r<1)$.

\section{Serum antibody responses}

In the BBB sheep, a significant rise in serum IgG level was observed 2 weeks post-exposure in the first phase (Group A) and after 3 weeks in the second phase (Groups A and B) of the experimental infections (Figure 5). On the other hand, this response was weak during the first phase but showed a significant rise after re-infection in the second phase $(P<0.05)$ in the INRA breed. The BBB lambs of Group A had higher serum IgG levels during their first exposure than the corresponding INRA group. However, similar first-exposure responses did not show any difference between the Group B animals of the two breeds in Phase II. The serum IgG responses against $\mathrm{L}_{3} \mathrm{CE}$ were very weak and comparable between breeds. In addition, serum IgA and mucus $\operatorname{IgG}$ and IgA levels were low and similar between infected groups (data not shown).
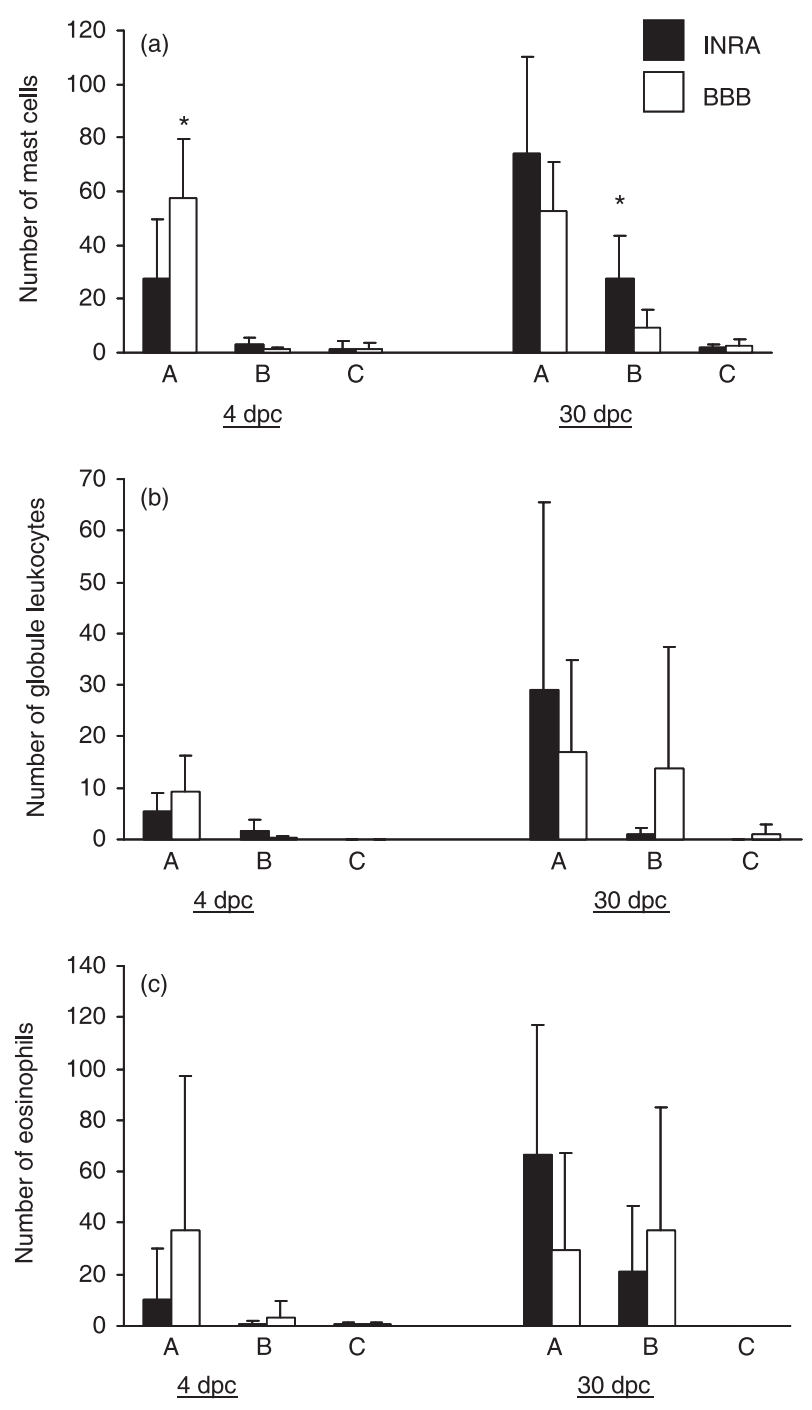

Figure 4 Cellular recruitment in the abomasal fundic mucosa: eosinophils (a), mast cells (b) and globule leucocytes (c) in infected and control animals. Values were expressed as sum of cell counts from five randomly selected microscopic fields $(\times 400)$. Asterisks indicate statistical differences between the two breeds $(P<0 \cdot 05)$.

\section{Serum pepsinogen concentration}

Both infected BBB Groups A and B showed peak serum pepsinogen values between 14 and 16 days after primaryinfection and re-infection while this occurred between 14 and 21 days in the INRA animals. In both breeds, values returned to pre-infection levels after treatment (Figure 6). Pepsinogen release into the systemic circulation was more intense in the BBB than in the INRA sheep $(P<0 \cdot 01)$ whereas no difference was noticed between Groups A and B of both breeds. 


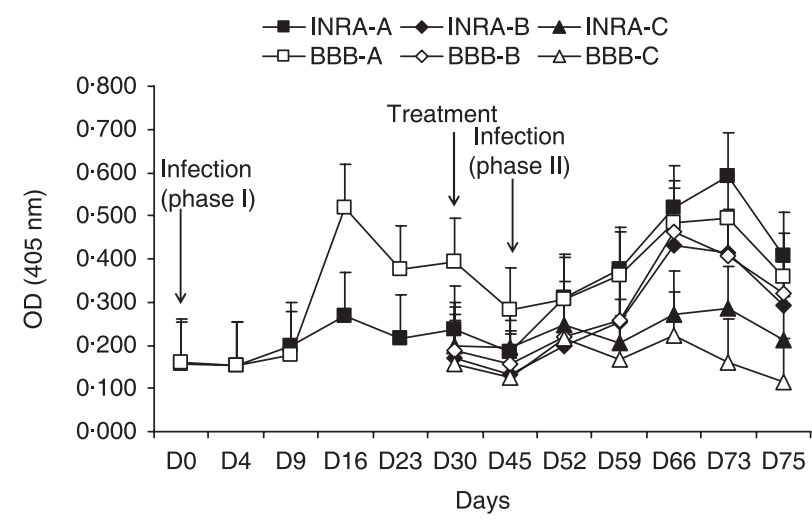

Figure 5 Serum IgG antibody responses to $H$. contortus adult ESP antigen in infected and control lambs. Optical densities were measured at $405 \mathrm{~nm}$.

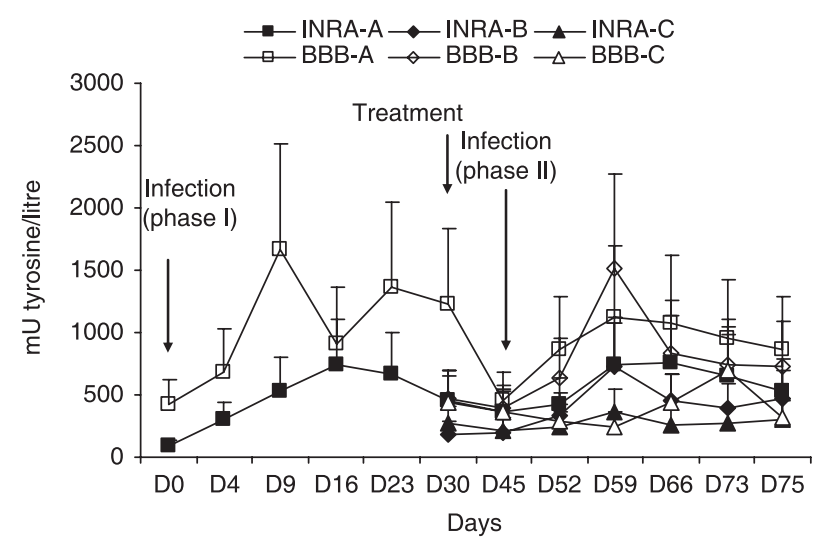

Figure 6 Kinetics of serum pepsinogen levels in infected and control animals. Values are given in $\mathrm{mU} / \mathrm{L}$ of serum.

\section{DISCUSSION}

\section{The adaptive immune response (cytokines and effector cells)}

The resistance of the BBB sheep to $H$. contortus infections has been well documented (27-30). In the present study, the resistance of BBB lambs to $H$. contortus was compared with that of the INRA 401 (INRA) breed. It was designed to investigate whether the higher resistance of BBB lambs was due to a more rapid and/or intense $\mathrm{Th}_{2}$ polarization and mobilization of associated effector cells and antibodies. The results show that a Th2-type immune response with characteristic cytokine gene expressions (IL-4, IL-5 and IL13) was evident in the two breeds and that this was consistent with previous data reported for the INRA genotype (7). Moreover, $30 \mathrm{dpc}$, mRNA gene expressions for these cytokines in the ALN of both infected BBB groups were more pronounced than in the INRA breed, which indicated the development of a more pronounced Th2-biased immune response in the former compared with the latter. Moreno et al. (31) have recently detected a QTL for resistance to $H$. contortus on ovine chromosome 5 in the INRA $\times$ BBB backcross lines. The most likely location of this QTL corresponded to the IL-13/IL-4/IL-5 region suggesting that the elaboration of these cytokines is genetically controlled. Similar findings were reported for $T$. colubriformis in resistant and susceptible lines of Romney sheep (32,33). In these sheep, the resistant animals were found to develop better Th2-polarized cytokine IL-5 and IL-13 (but not IL4) gene expressions than the susceptible lines. Moreover, the persistence of IL-5 mRNA expression in the BBB and its down-regulation in the INRA breed, together with its strong positive correlation to the numbers of blood and abomasal tissue eosinophils in the former, may suggest an enhanced contribution of IL-5 in the functional mobilization of these cells in the resistant compared with the susceptible breed. In rodent models, the production of some Th2 cytokines (particularly IL-5) can be down-regulated in chronic helminth infections irrespective of the continued production of IL-4 (34). It is possible therefore, that some inflammatory and protective immune responses, such as IL-5 dependent responses, could have been switched off in the INRA breed.

Irrespective of differences in cytokine expression in the ALN and eosinophil levels in blood, abomasal Th2 cytokine mRNA expression, tissue recruitment of characteristic effector cells, and local and systemic antibody responses remained similar between the BBB and INRA breeds. Similar findings were reported by Amarante et al. (35) where resistant Santa Ines, and susceptible Suffolk and Ile de France breeds of sheep had comparable numbers of abomasal eosinophils and mast cells after infection with $H$. contortus. On the other hand, Bricarello et al. (36) showed higher abomasal eosinophil and globule leucocyte counts in a resistant (Crioula Lanada) compared with the susceptible (Corriedale) breed after infection with $H$. contortus. Both before and after infection in this study, the resistant breed had a consistently higher blood eosinophilia but a similar density of tissue eosinophils compared with the susceptible breed. Eosinophil mobilization from the bone marrow into the systemic circulation could be mediated by IL-5 and the expression of this may have differed between the two breeds; however, the similar levels of eosinophil-active chemokine (eotaxin) observed and/or the possible release of parasitederived eosinophil chemotactic factors $(37,38)$ may explain the similar numbers of eosinophils observed in the AFM of the two breeds of sheep. Moreover, for animals of different genetic background, variations may also exist in the period during which maximal tissue recruitment of effector cells can be observed (39). In this study, day 4 and day 30 were 
the only two time points chosen to observe the early and late profiles of cytokines and effector cells, and this may not necessarily represent the dynamics of this aspect of the immune response between these two necropsy dates.

Interestingly, following primary infection and re-infection, the BBB lambs showed higher blood pepsinogen levels than the INRA lambs. As an increase in serum pepsinogen levels may signal abomasal tissue damage and disturbance in vascular permeability (39), minimizing the local inflammatory reactions by limiting cellular recruitment and other effector mechanisms may be an advantage for the animal although the effect of this response on parasite survival remains undefined.

\section{Effect of breed and re-infection on the regulation of $H$. contortus populations}

On the basis of the parasitological parameters, the BBB lambs appeared more resistant than the INRA lambs during their first exposure to $H$. contortus. The lower numbers of worms in the abomasum both at 4 and 30 days post-primary infection, and the reduced female worm size and number of eggs in utero observed in the BBB animals are without doubt responsible for the observed drastic reduction in FEC compared to the values recorded for the corresponding INRA groups. This was also associated with retardation in worm development, which was reflected by the higher number of immature worms and the longer prepatent period observed in the tropical breed. The lower FEC and worm establishment rate in the primary-infected BBB lambs compared with their INRA counterparts is in agreement with the earlier reports of Aumont et al. (18) and Gruner et al. (19). The negative correlation between FEC and worm length (in the INRA sheep) or worm burden (in the BBB animals) with the observed blood eosinophilia, suggests a possible role for these cells in the resistance of sheep to $H$. contortus. This agrees with the findings of Stear et al. (40) and Buddle et al. (41).

To study the effect of immunization on the immune response and parasite development, previously infected animals (Group A) were ivermectin treated and then reinfected with the same dose of $H$. contortus larvae. No significant differences in the immunological parameters measured were observed after the primary-infection and re-infection, with the exception of an elevation in the level of IL-5 four days after re-infection and a consistently higher blood eosinophilia throughout the rest of the experimental period in the BBB breed. Despite these observations, the INRA sheep were able to reduce worm development and fecundity in terms of female size, eggs in utero and number of immature worms after re-infection compared with after primary-infection. This is consistent with the findings of
Lacroux et al. (7) in INRA 401 lambs. Contrary to the findings in the lambs of the INRA breed, the regulation of the $H$. contortus populations did not change after re-infection in the BBB lambs. This may suggest that the mechanism governing resistance to this parasite in the $\mathrm{BBB}$ lambs was efficient enough early in the first exposure and was not enhanced during the second infection. Bahirathan et al. (42) reported that suckling lambs of the Gulf Coast Native breed developed resistance to $H$. contortus infection after their first exposure to infection. Similarly, Florida Native lambs had lower FEC compared with lambs of the Rambouillet breed during their first exposure to natural infection while there was no difference between the two breeds of lambs after the second exposure (43). This is in contrast to the findings of Gauly et al. (44) for Rhön and Merinoland breeds, Aumont et al. (18) for the Black Belly and INRA 401 sheep, and Gamble and Zajac (16) for St. Croix and Dorset lambs; in all of these studies, increased resistance and breed differences were demonstrated in re-infected animals. While differences in experimental protocols, and the age and breed of animals could be responsible for variations in the findings of different studies, the precise origin of these discrepancies is not yet clear.

In conclusion, both the BBB and INRA breeds of animals used in this study showed a Th2-type immune response with characteristic cytokine gene expressions and a corresponding recruitment of effector cells. While elevated levels of Th2 cytokine mRNA expression and persistently higher blood eosinophilia characterized the response in the BBB lambs, tissue recruitment of effector cells, and local and systemic antibody responses remained similar between the two breeds. The BBB lambs again proved that this breed is highly resistant to $H$. contortus but since the regulation of the parasite populations seems to occur very quickly in these animals, the concurrent involvement of an innate immune response cannot be excluded. In contrast, the INRA 401 lambs showed an enhanced response in terms of regulation of the parasite's lifecycle after re-infection, although a correlation in the aspects of immune response examined in this study could not be demonstrated.

\section{ACKNOWLEDGEMENTS}

We are greatly indebted to the technical staff of La Sapinière INRA experimental station (INRA Department of Animal Genetics) for providing us with the two breeds of sheep. We thank Prof. Jimmy Duncan for proof reading the English language and for his valuable comments and suggestions. This work was supported by the FEOGA program (Region centre) 'Résistance génétique aux maladies'. Mr Getachew Terefe was supported by a grant from the French Embassy in Ethiopia. 


\section{REFERENCES}

1 Balic A, Bowles VM \& Meeusen ENT. The immunobiology of gastrointestinal nematode infections in ruminants. Adv Parasitol 2000; 45: 181-241.

2 Daly CM, Mayrhofer G \& Dent LA. Trapping and immobilization of Nippostrongylus brasiliensis larvae at the site of inoculation in primary infections of interleukin-5 transgenic mice. Infect Immun 1999; 67: 5315-5323.

3 Barger IA, Le Jambre LF, Georgi JR \& Davies HI. Regulation of Haemonchus contortus populations in sheep exposed to continuous infection. Int $J$ Parasitol 1985; 15: 529-533.

4 Gill HS, Watson DL \& Brandon MR. Monoclonal antibody to $\mathrm{CD}^{+} \mathrm{T}$ cells abrogates genetic resistance to Haemonchus contortus in sheep. Immunology 1993; 78: 43-49.

5 Peña MT, Miller JE \& Horohov DW. Effect of CD4+ T lymphocyte depletion on resistance of Gulf Coast Native lambs to Haemonchus contortus infection. Vet Parasitol 2006; 138: 240-246.

6 Gill HS. Cell-mediated immunity in Merino lambs with genetic resistance to Haemonchus contortus. Int J Parasitol 1994; 24: 749-756.

7 Lacroux C, Nguyen THC, Andreoletti O et al. Haemonchus contortus (Nematoda: Trichostrongylidae) infection in lambs elicits an unequivocal Th2 immune response. Vet Res 2006; 37: 607-622.

8 Schallig HDFH. Immunological responses of sheep to Haemonchus contortus. Parasitology 2000; 120: S63-S72.

9 Balic A, Cunningham CP \& Meeusen ENT. Eosinophil interactions with Haemonchus contortus larvae in the ovine gastrointestinal tract. Parasite Immunol 2006; 28: 107-115.

10 Klion AD \& Nutman TB. The role of eosinophils in host defence against helminth parasites. J Allergy Clin Immunol 2004; 113: 30-37.

11 Miller JE \& Horohov DW. Immunological aspects of nematode parasite control in sheep. J Anim Sci 2006; 84: E124-E132.

12 Balic A, Bowles VM \& Meeusen ENT. Mechanisms of immunity to Haemonchus contortus infection in sheep. Parasite Immunol 2002; 24: 39-46.

13 Stear MJ, Bishop SC, Doligalska M et al. Regulation of egg production, worm burden, worm length and worm fecundity by host responses in sheep infected with Ostertagia circumcincta. Parasite Immunol 1995; 17: 643-652.

14 Amarante AFT, Bricarello PA, Rocha RA \& Gennari SM. Resistance of Santa Ines, Suffolk and Ile de France sheep to naturally acquired gastrointestinal nematode infections. Vet Parasitol 2004; 120: 91-106.

15 Burke JM \& Miller JE. Relative resistance of Dorper crossbred ewes to gastrointestinal nematode infection compared with St. Croix and Katahdin ewes in the south-eastern United States. Vet Parasitol 2002; 109: 265-275.

16 Gamble HR \& Zajac AM. Resistance of St. Croix lambs to Haemonchus contortus in experimentally and naturally acquired infections. Vet Parasitol 1992; 41: 211-225.

17 Woolaston RR \& Baker RL. Prospects of breeding small ruminants for resistance to internal parasites. Int $J$ Parasitol 1996; 26: 845-855.

18 Aumont G, Gruner L \& Hostache G. Comparison of the resistance to sympatric and allopatric isolates of Haemonchus contortus of Black belly sheep in Guadeloupe (FWI) and of INRA sheep in France. Vet Parasitol 2003; 116: 139-150.
19 Gruner L, Aumont G, Getachew T et al. Experimental infection of Black Belly and INRA straight and crossbred sheep with trichostrongyle nematode parasites. Vet Parasitol 2003; 116: 239-249.

20 Raynaud JP. Etude de l'efficacité d'une technique de coproscopie quantitative pour le diagnostic de routine et le contrôle des infestations parasitaires des bovins, ovins, équins et porcins. Ann Parasitol Hum Comp 1970; 45: 301-342.

21 Kloosterman A, Albers GA \& Van den Brink R. Genetic variation among calves in resistance to nematode parasites. Vet Parasitol 1978; 24: 353-368.

22 Dawkins HJ, Windon RG \& Eagleson GK. Eosinophil responses in sheep selected for high and low responsiveness to Trichostrongylus colubriformis. Int J Parasitol 1989; 19: 199205.

23 Terefe G, Yacob HT, Grisez C et al. Haemonchus contortus egg excretion and female length reduction in sheep previously infected with Oestrus ovis (Diptera: Oestridae) larvae. Vet Parasitol 2005; 128: 271-283.

24 Lowry O, Rosbrough NJ, Fan AL \& Randal RJ. Protein measurement with folin phenol reagent. J Biol Chem 1951; 193: $265-275$.

25 Jacquiet P, Ngoc TTT, Nouvel X et al. Regulation of Oestrus ovis (Diptera: Oestridae) populations in previously exposed and naïve sheep. Vet Immunol Immunopathol 2005; 105: 95-103.

26 Dorny P \& Vercruysse J. Evaluation of a micro method for the routine determination of serum pepsinogen in cattle. Res Vet Sci 1998; 65: 259-262.

27 Courtney CH, Parker CF, McClure KE \& Herd RP. Resistance of exotic and domestic lambs to experimental infection with Haemonchus contortus. Int J Parasitol 1985a; 15: 101-109.

28 Courtney CH, Parker CF, McClure KE \& Herd RP. Resistance of non-lambing exotic and domestic ewes to naturally acquired gastrointestinal nematodes. Int J Parasitol 1985b; 15: 239-245.

29 Notter DR, Andrew SA \& Zajac AM. Responses of hair and wool sheep to a single fixed dose of infective larvae of Haemonchus contortus. Small Rumin Res 2003; 47: 221-225.

30 Yazwinski TA, Goode L, Moncol DJ, Morgan GW \& Linnerud AC. Haemonchus contortus resistance in straightbred and crossbred Barbados Black Belly sheep. J Anim Sci 1980; 51: 279-284.

31 Moreno C, Gruner L, Scala A et al. QTL for resistance to internal parasites in two designs based on natural and experimental conditions of infection. Proceedings of the 8th World Congress on Genetics Applied to Livestock Production 2006.

32 Pernthaner A, Cole SA, Morrison L \& Hein WR. Increased expression of interleukin-5 (IL-5), IL-13 and tumor necrosis factor $\alpha$ genes in intestinal lymph cells of sheep selected for enhanced resistance to nematodes during infection with Trichostrongylus colubriformis. Infect Immun 2005; 73: 2175 2183.

33 Pernthaner A, Cole SA, Morrison L, Green R, Shaw RJ \& Hein WR. Cytokine and antibody subclass responses in the intestinal lymph of sheep during repeated experimental infections with the nematode parasite Trichostrongylus colubriformis. Vet Immunol Immunopathol 2006; 114: 135-148.

34 Maizels RM, Balic A, Gomez-Escobar N, Nair M, Taylor MD \& Allen JE. Helminth parasites - masters of regulation. Immunol Rev 2004; 201: 89-116.

35 Amarante AFT, Bricarello PA, Huntley JF, Mazzolin LP \& Gomes JC. Relationship of abomasal histology and parasitespecific immunoglobulin A with the resistance to Haemonchus 
contortus infection in three breeds of sheep. Vet Parasitol 2005; 128: 99-107.

36 Bricarello PA, Gennari SM, Oliveira-Sequeira TCG, Vaz CMSL, Gonçalves de Gonçalves I \& Echevarria FAM. Worm burden and immunological responses in Corriedale and Crioula Lanada sheep following natural infection with Haemonchus contortus. Small Rumin Res 2004; 51: 75-83.

37 Wildblood LA, Kerr K, Clark DA, Cameron A, Turner DG \& Jones DG. Production of eosinophil chemoatractant activity by ovine gastrointestinal nematodes. Vet Immunol Immunopathol 2005; 107: 57-65.

38 Dixon H, Blanchard C, de Schoolmeester ML et al. The role of Th2 cytokines, chemokines and parasite products in eosinophil recruitment to the gastrointestinal mucosa during helminth infection. Eur J Immunol 2006; 36: 1753-1763.

39 Simpson HV. Pathophysiology of abomasal parasitism: is the host or parasite responsible? Vet J 2000; 166: 177-191.

40 Stear MJ, Henderson NG, Kerr A et al. Eosinophilia as a marker of resistance to Teladorsagia circumcincta in Scottish Blackface Lambs. Parasitology 2002; 124: 553-560.

41 Buddle BM, Jowett G, Green RS, Douch PG \& Risdon PL. Association of blood eosinophilia with the expression of resistance in Romney lambs to nematodes. Int J Parasitol 1992; 22: 955-960.

42 Bahirathan M, Miller JE, Barras SR \& Kearney MT. Susceptibility of Suffolk and Gulf Coast Native suckling lambs to naturally acquired strongylate nematode infection. Vet Parasitol 1996; 65: 259-268.

43 Amarante AF, Craig TM, Ramsey WS, Davis SK \& Bazer FW. Nematode burdens and cellular responses in the abomasal mucosa and blood of Florida Native, Rambouillet and crossbreed lambs. Vet Parasitol 1999; 80: 311-324.

44 Gauly M, Kraus M, Vervelde L, van Leeuwen MA \& Erhardt G. Estimating genetic differences in natural resistance in Rhon and Merinoland sheep following experimental Haemonchus contortus infection. Vet Parasitol 2002; 106: 55-67. 